\title{
Impact of Land Use Changes on Wildlife Population in Nairobi National Park and Kitengela Dispersal Areas in Kenya
}

\author{
Lynnette Mwari Kiboro ${ }^{1}$, Christopher Nkonge Kiboro ${ }^{2}$ \\ ${ }^{1}$ Kenya Wildlife Service Training Institute, Deparment of Wildlife and Environnent, P.O. Box 842Naivasha \\ ${ }^{2}$ Chuka University, Faculty of Arts and Humanities, P.O. Box 109-60400, Chuka
}

\begin{abstract}
Today, sustainable management of biodiversity has become a major global concern. This concern has been prompted by the realization that biodiversity is rapidly being lost through increased use of species and widespread alteration of habitats due to human activities such as cultivation, pastoralism and urbanization. The rapidly increasing human population and changes in lifestyles have a direct threat to wildlife conservation. Land subdivision, human settlement and poor planned developments around wildlife dispersal areas are particularly posing a major threat to wildlife population. This paper provides empirical analysis of the impact of land use changes on wild animals' population around the Nairobi National Park and Kitengela Conservation areas for the period between 2000 and 2008 .
\end{abstract}

Keywords: Conservation, Dispersal area, Land-use changes, Wildlife

\section{Introduction}

Kenya is well known for being rich in wildlife species. However, her habitats and wildlife corridors continue to be threatened by human activities. Although wildlife in Kenya is essentially supposed to be confined within protected areas, the stretch of land adjacent to the protected areas plays a vital role to their survival. [1], [2],[3], show that areas of land which connect protected areas, otherwise known as corridors, play an important role of reducing the threats to the biodiversity of an ecosystem by providing access to migratory routes and other resources such as habitats, food, predation, cover and breeding sites. These studies focused on the effects of land-use changes on migratory routes but did not seek to establish their effects on wildlife population. This paper seeks to fill this gap.

In Kenya, Kitengela rangeland is extremely important for wildlife conservation as it forms the dispersal area for the wildlife of Nairobi National Park. Kitengela area lies to the immediate South of the Nairobi National Park and is characterized by a variety of human activities which are not mutually compatible with wildlife conservation. In the recent past, Kitengelaarea formed a remarkable rangeland for wildlife dispersal corridor. Today, it is a hub of human activities which include permanent settlements, agriculture, pastoralism and land sub-divisions.

Parcels of land in Kitengela are increasingly becoming smaller and smaller due to rapid land sub-division [4].There are now more fences that are joining along the roads and along the Embakasi River such that for wild animals to migrate to the southern part of the ecosystem specifically the Lenchani and Enkirgirri ecosystems, they have to pass through privately owned parcels of land and then cross the Namanga road to and from the Park. These changes have occurred in the recent years due to increase in human population, informal settlements and illegal developments particularly in Athi-River region. These have in the meantime enormously affected conservation of wildlife in Nairobi National Park and the Athi-Kapiti plains especially due to human wildlife conflicts in the area.

Nairobi National Park is also becoming increasingly isolated habitat as the land surrounding it (Kitengela) is rapidly getting fragmented due to human activities. This situation presents a grim future for the wildlife that contributes substantially to the national revenue through tourism. Thus this paper examines the land-use changes that have occurred in the period between 2000 and 2008 and their implications on the wild animals' population both in Nairobi and Kitengela areas.

\section{Literature Review}

Across the world, expansion and intensification of unplanned land-use outside the protected areas is resulting in changes in ecological function and biodiversity within protected areas. According to [5], the use of land to provide goods and services for human use results in an extensive human alteration of the earth system, thus affecting the structure and function of ecosystems. The impacts of land-use changes along the wildlife dispersal areas on wildlife and the interactions between humans and wildlife are sure means to long-term degradation of ecosystem. [6],[7], point out that some of the conspicuously observable changes in land-use are the sub-division of land and fencing with the view to earning more money and leasing of land by those adjacent to the protected areas to immigrant farmers or to practice cultivation themselves. These types of land-use result in loss of wildlife dispersal areas. Moreover, once land is subdivided, the new owners may choose to fence round their land thus fragmenting wildlife habitats and blocking their migratory routes [6].

[8] observes that the biggest threat to survival of wildlife species is loss of habitat caused by increased human population and encroachment. Expanding human population 


\section{International Journal of Science and Research (IJSR) \\ ISSN (Online): 2319-7064 \\ Index Copernicus Value (2013): 6.14 | Impact Factor (2015): 6.391}

suggest a number of consequences which are not exception in the case of Nairobi National Park. First, there is increased change in land-use in the area. Secondly, it means change from pastoralism to increased agriculture in the area. [8] Further reports that since 1980 s, wildlife dispersal areas adjacent to Nairobi National Park have been cultivated. The original land owners, the Maasai, are selling or leasing their land to farmers who wish to maximize on the agricultural potential of the fertile lands.

Further [9] reports that the Kitengela and Athi-Kapiti plains form an essential component of the Nairobi National Park ecosystem since they serve as the only open migratory corridors for wildlife. Also, [10] argues that migratory corridors are absolutely necessary for the success of wildlife in semi-arid lands. Thus, the Kitengela dispersal area is the lifeline for the wildlife of Nairobi National Park. However, due to increased land-use and the associated changes such as urban development in Nairobi including infrastructural development such as roads construction, the wildlife dispersal zones have significantly reduced.

[11] identifies development of infrastructure and increasingly sedentary lifestyles, both of which occupy former wildlife habitat and utilize resources once used by wildlife as the potential threats which lower the integrity of migratory corridors. Corridors play an important role of preventing wildlife from being restricted to protected areas that are slowly becoming isolated. However, with the increase in human population and the resulting encroachment, dispersal areas are slowly diminishing.

\section{Methods}

Two data sets were used. The first set consisted of primary data collected using structured questionnaires from a sample of 100 respondents selected through simple random sampling. The questionnaires sought to capture data on the local communities' awareness of the dispersal area, its location and observed trends in wildlife population over the years. The second set, consisted of wildlife census data from Kenya Wildlife Services.

\section{Results and Discussions}

The data obtained from the respondents interviewed indicated that all of them were aware of the wildlife dispersal area. To test their level of awareness, the respondents were asked whether they knew the location of wildlife dispersal area. Surprisingly, all the respondents precisely stated that it lies in Kitengela, Athi-Kapiti plains and Isinya-Kipeto plains. This high level of awareness is perhaps as a result of the regular community sensitization programs between Kenya Wildlife Service officers and the surrounding communities. The study further assessed the respondents' knowledge about changes in the dispersal area. This was achieved by inquiring the respondents to identify factors that influenced the changes.

Several factors were identified as responsible for the changes in the dispersal area. Human settlement was identified as among the factors contributing to the reducing in size of the dispersal area by $24 \%$ of the total respondents. Table 1 also shows that fencing and land-subdivision was another cause of changes in the dispersal area as identified by $23 \%$ of the respondents. Flower faming was also identified by $23.0 \%$ of the respondents as a contributor to the changes observed in the dispersal area while another $23.0 \%$ identified fencing and land sub-division. Other factors mentioned were mining $(15 \%)$ and sale of land (15\%).

Table 1: Land Use Activities Influencing Changes in the Size of Dispersal Area

\begin{tabular}{|c|c|c|}
\hline Land-use Activity & Frequency & Percent \\
\hline Fencing and land sub-division & 23 & 23 \\
\hline Flower farming & 23 & 23 \\
\hline Human settlement & 24 & 24 \\
\hline Mining and quarrying & 15 & 15 \\
\hline Sale of land & 15 & 15 \\
\hline Total & 100 & 100 \\
\hline
\end{tabular}

To determine the impact of land-use changes on wildlife conservation, it was necessary to observe changes in the wildlife population over time as well as factors responsible for the changes observed. To achieve this, respondents' opinions were sought and compared with animals' population data from the Kenya Wildlife Service (KWS). Although the respondents have no ability to provide precise changes in form of quantitative figures, their qualitative observations were dependable since they were able to observe whether or not a herd of particular species was increasing or decreasing over time. Indeed, when asked about the population trend of the wildlife in the area, all the participants were unanimous that the wildlife population was dropping. The respondents further identified various factors that they associated with the observed changes in the wildlife population in the study area.

Majority of the respondents (56\%) identified human development and encroachment as the major cause of the reduction in the wildlife population. This observation is plausible since some animals such as zebras, giraffes, wildebeests and impalas after out-migrating may afterwards return and find migratory routes blocked as a result of human encroachment. Consequently, the animals get disoriented on realization they are in the midst of human settlement. Additionally, they get exposed to poachers and other predators, thus drastically reducing their population.

Apart from human development and encroachment, 21\% of the total respondents mentioned drought and climate change as having contributed to the dwindling numbers in the wildlife population. This is also a credible factor because prolonged spells of drought reduces the amount of pasture in the protected areas thus driving animals out of parks in search of better fields for grazing. In the process, animals are exposed to predators or may adapt to new habitats. These processes directly reduce population of wildlife in their original habitats. Also, the out-migration of some species (for example herbivores) may seriously affect the food chain which can lead to deaths in other species (carnivores). For example, when the herbivores are migrating, the carnivores are compelled to trail them. This can attract the attention of the poachers who kill them for their claws, teeth and hide. 


\section{International Journal of Science and Research (IJSR) \\ ISSN (Online): 2319-7064 \\ Index Copernicus Value (2013): 6.14 | Impact Factor (2015): 6.391}

Nearly $20 \%$ of the respondents also said that destruction of the wildlife habitats contributed to the decrease in their population while $4 \%$ identified poaching as another cause of drop in wildlife population. These observations are plausible since the destruction of habitats can interfere with the breeding patterns of certain species. Similarly, others may die depending on the type of hazards they are exposed to as a result of habitat destruction. For example, destruction through fire can have both direct and indirect effects such as immediate deaths or death by starvation as a result of lack of pastures.

Table 2: Respondents' Observed Changes in Wildlife Population

\begin{tabular}{|c|c|c|}
\hline $\begin{array}{c}\text { Are there changes observed in the } \\
\text { population? }\end{array}$ & Frequency & Percent \\
\hline Yes & 100 & 100 \\
\hline No & 0 & 0 \\
\hline Total & 100 & 100 \\
\hline $\begin{array}{c}\text { What is the population trend of } \\
\text { wild animals in the area? }\end{array}$ & 99 & 99 \\
\hline Decreasing & 1 & 1 \\
\hline Increasing & 100 & 100 \\
\hline Total & & \\
\hline $\begin{array}{c}\text { What factors contribute to the } \\
\text { changes in wild animals' } \\
\text { population? }\end{array}$ & 19 & 19 \\
\hline Destruction of their habitat & 21 & 21 \\
\hline Drought and climate change & 56 & 56 \\
\hline $\begin{array}{c}\text { Human development and } \\
\text { encroachment }\end{array}$ & 4 & 4 \\
\hline Poaching & 100 & 100 \\
\hline Total & & \\
\hline
\end{tabular}

Based on the above results, it was evident that wildlife population was on a downward trend for most of the species over the years. To prove this, there was need to use empirical data from Kenya Wildlife Services on population trends for each species for the period2000-2008.

Table 3: Wildlife Population Trends

\begin{tabular}{|c|c|c|c|c|c|c|c|c|c|} 
Species & 2000 & 2001 & 2002 & 2003 & 2004 & 2005 & 2006 & 2007 & 2008 \\
\hline
\end{tabular}

\begin{tabular}{|l|l|l|l|l|l|l|l|l|l|}
\hline Wildebeest & 2508 & 17 & 21 & 16 & 107 & 288 & 643 & 95 & 121 \\
\hline
\end{tabular}

\begin{tabular}{|l|l|c|c|c|c|c|c|c|c|}
\hline Burchell's & 2237 & 368 & 462 & 357 & 877 & 1266 & 1034 & 942 & 1041 \\
\hline
\end{tabular}

\begin{tabular}{|c|c|c|c|c|c|c|c|c|c|}
\hline $\begin{array}{c}\text { Zurchell } \\
\text { zebra }\end{array}$ & 223 & 368 & 462 & 357 & 877 & 1266 & 1034 & 942 & 1041 \\
\hline $\begin{array}{c}\text { Grant } \\
\text { Gazelle }\end{array}$ & 99 & 72 & 52 & 42 & 73 & 94 & 67 & 46 & 51 \\
\hline $\begin{array}{c}\text { Thomson } \\
\text { Gazelle }\end{array}$ & 166 & 94 & 112 & 58 & 73 & 92 & 76 & 70 & 77 \\
\hline Buffalos & 125 & 108 & 194 & 162 & 142 & 225 & 293 & 141 & 291 \\
\hline Ostrich & 121 & 94 & 76 & 93 & 86 & 115 & 125 & 81 & 90 \\
\hline Total & 5256 & 753 & 917 & 728 & 1358 & 2080 & 2238 & 1375 & 1671 \\
\hline
\end{tabular}

Source: Kenya Wildlife Service (2008).

Table 3 provides a summary of the population trends of the wildlife species commonly found in the Nairobi National Park for the study period (2000-2008).Using the population for 2000 as the baseline for comparison, it is apparent that there was a sharp drop in the general wildlife population for the entire study period. For example, in 2000, there were a total of 5256 animals and in 2008 the total population had dropped to 1671 . This presents a $68.2 \%$ decline in the total population.
The study went further beyond the changes in the general population to changes in the individual species. The aim was to identify the species that were highly threatened by the changes taking place. All the species other than buffalos had a negative deviation in their population. During the nine years period, buffalos' population had grown by $132.8 \%$. In the same period, wildebeest population had sharply dropped by $95.1 \%$. This was the highest and most alarming decline amongst all the species. This can be attributed to the migratory behavior of wildebeest that is characterized by massive outmigration. On coming back, they may find the migratory corridors blocked forcing them to move to another location, thus drastically reducing their population in the park. Other species that had more than $50 \%$ decline in population were Burchell's Zebra (53.4\%) and Thomsom Gazelle (53.6\%). The population of Grant Gazelle and Ostrich had dropped by $48.4 \%$ and $25.6 \%$ respectively. These results corroborates the earlier findings obtained from interviews with the respondents.

\section{Conclusion}

This paper has shown that changes in land use in areas adjacent to protected areas affect wildlife population. The key land use changes identified as affecting wildlife population were fencing of areas that traditionally were dispersal areas for wildlife, land sub-division and sale of land, mining and quarrying among others. All these activities are incompatible with wildlife conservation strategies. The findings show that the size of dispersal area and wildlife population is intricately related. Therefore it is crucial for the government and other stakeholders to formulate legislations on conservation and protection of dispersal areas with the view to sustaining and reviving the already diminishing wildlife populations.

\section{References}

[1] H.F. Heady and E.B. Heady, Range and Wildlife Management in the Tropics, Longman Inc, New York, 1982.

[2] W.D.Newmark, "Insularization of Tanzanian parks and the local extinction of large mammals", Conservation Biology, 10(6): pp.1549-1556, 1996.

[3] G.K.Meffe and C.R.Caroll, Principles of Conservation Biology, Sinauer Associates, Inc Sunderland, Massachusetts, 1997.

[4] A.Mwangi and E. Warinda, "Socio-economic Dimensions of Sustainable Wildlife Conservation in the Kitengela Wildlife Dispersal Area", Final Report, African Conservation Center, 1999.

[5] P.M, Vitousek, A.M, Harold, L. Jane, M.M Jerry "Human domination of earth's ecosystems", Science, 277(5325),pp. 494-499, 1997.

[6] K. Kimani, and J. Pickard, "Recent trends and implications of group ranch sub-division and fragmentation in Kajiado District, Kenya", The Geographic Journal, 164 (10), pp. 202.1998.

[7] S.K Seno, and W.W. Shaw, "Land Tenure Policies, Maasai Traditions, and Wildlife Conservation in Kenya”, Society and Natural Resources, 15, pp. 79-88, 2002. 


\section{International Journal of Science and Research (IJSR) \\ ISSN (Online): 2319-7064}

Index Copernicus Value (2013): 6.14 | Impact Factor (2015): 6.391

[8] V. Morell, "Surrounded: Civilization is Encroaching on Nairobi National Park (Nairobi wildside)," International Wildlife, 27 (4), pp.38-44, 1996.

[9] K.,Western, "Nairobi National Park is slowly being strangled by development", Swara 20(1), pp. 19$20,1997$.

[10]K...L, Harris, W.W Shaw,andJ. Schelhas, "Urban Neighbors? Wildlife Related Attitudes and Behaviors near Federally Protected Areas in Tucson Arizonia, USA", Nature Areas Journal 17(2), pp.144-148, 1997.

[11]B.E Wishitemi, and M.M Okello, "Application of the Protected Landscape Model in Southern Kenya", Parks 13(2),pp12-21. 2003. 